UDC: 581.47

\title{
MORPHOLOGICAL AND ANATOMICAL STRUCTURE OF CAMPANULA LATIFOLIA L. FRUIT
}

\section{R. Andreychuk, A. Odintsova}

Ivan Franko National University of Lviv, 4, Hrushevskyi St., Lviv 79005, Ukraine e-mail:roksolana_roksa@i.ua

Andreychuk R., Odintsova A. Morphological and anatomical structure of Campanula latifolia L. fruits. Studia Biologica, 2019: 13(1); 95-105 • DOI: https://doi.org/10.30970/sbi.1301.593

The inner fruit structure in Campanula latifolia L. was studied using light microscopic technique. Our aim was to revise the dehiscence mode in the fruit and find out from which part of ovary the axicorn - peculiar organ inside ovary, is formed and which tissues it contains. The fruit of $C$. latifolia has a persistent central column with three septa attached. We showd that during fruit ripening, three dips appear in the lower fruit part, followed by formation of a hippocrepiform slit at the lower margin of each dip, providing an opening. The valves that cover each opening bend outwards. Exocarpium is composed of one-cell layer with non-lignified walls. Mesocarpium is multilayered, mostly parenchymatous, with numerous vascular bundles. Endocarpium is uniseriate, nonlignified, composed of small flattened cells. Vascular system of the fruit wall is composed of 10-12 large concentric vascular bundles with annular xylem organized in a single ring. In the lower part of the ovary, the inner cell layers of the mesocarpium as well as parenchyma of septas become lignified. This lignified tissue contains isodiametric and polygonal cells with thick walls. Before the fruit wall opens, it is visible that septa detach from a central column just on the boundary between lignified and non-lignified parenchyma. On the longitudinal sections, lignified parenchyma has a form of vertical band extending from the base to the top of the ovary. This vertical band of tissue differentiating early during the fruit development and being well-distinguished from the adjacent parenchyma is the axicorn. In C. latifolia, it has a complex, mattock-like shape. The lower margin of axicorn causes formation of the hippocrepiform opening in the ovary wall. Our investigation provides an evidence that the axicorn is not an organ sui generis inside the ovary of Campanula, but it is merely a band of lignified parenchyma of the mesocarpium and especially of septa which is commonly found also in other members of Campanulaceae. The fruit of $C$. latifolia is considered to be an inferior trilocular capsule with septifragal-hippocrepiform dehiscence.

○ 2019 R. Andreychuk et al. Published by the Ivan Franko National University of Lviv on behalf of Біологічні Студії / Studia Biologica. This is an Open Access article distributed under the terms of the Creative Commons Attribution License (http://www.budapestopenaccessinitiative.org/ and Creative Commons Attribution 4.0 License), which permits unrestricted reuse, distribution, and reproduction in any medium, provided the original work is properly cited.

ISSN 1996-4536 (print) • ISSN 2311-0783 (on-line) • Біологічні Студії / Studia Biologica • 2019 • Том 13/№1 • С. 95-105 
Keywords: giant bellflower, inferior capsule, fruit wall, septifragal dehiscence, hippocrepiform slit, axicorn

\section{INTRODUCTION}

Morphological structure, types and dehiscense mode of fruits provide an important information for the taxonomy and phylogeny of different taxa. Therefore, the study of fruit morphogenesis and dehiscense are topical problems in many modern studies [3, 7 , 10, 15]. The Campanulaceae Juss. family is large (almost 2400 species and 84 genera) and morphologically variable [13]. The basic morphological types of the campanulaceous fruit have been established [11], and the system of the family has been developed $[6,13,21]$. The main fruit type in Campanulaceae is an inferior axicorn capsule found in Campanula and many other genera: Adenophora Fisch., Asyneuma Griseb. et Schenk, Campanula L., Legousia Durande, Phyteuma L. Baccate fruits, poricidal, foraminicidal, fissuricidal and valvate capsules of diverse structure have also been found in other representatives of the family [11].

In the flora of Ukraine 42 species from 6 genera of the Campanulaceae are referred [17]. The greatest genus in the family is Campanula L. Species of the genus Campanula are annual, biennial or perennial herbs with flowers being solitary or composed in different types of inflorescences. Flowers are pentamerous, the calyx persistent in the fruit, the corolla is bell-shaped. The ovary is inferior, 2-, 3- or 5-locular. There is a nectar disc on the roof of the ovary. Fruit is a multiseeded capsule, erect or pendant. The capsule opens with basal, medial or apical pores also called valves [13]. A.A. Kolakovsky [11] established for the genus Campanula a new type of fruit - an axicorn capsule, which opens by means of axicorn, defined as „a specialized organ, usually attached to a central column, or not often shifted to the outer wall of the capsule, which actively bends like a horn during the fruit drying and provides dissemination of seeds through the formation of openings on the surface of the capsule or sometimes also on the disk" [11]. The presence of axicorns was confirmed and its shape was described in various species of Campanula $[5,11,16]$. However, there is still no suggestion about the morphological identity of axicorns and the way of their functioning. Our aim was to revise the dehiscense mode in the fruit of Campanula latifolia L. - the type species of the genus, and find out from which part of ovary the axicorn is formed and which kind of tissues it contains.

\section{MATERIAL AND METHODS}

Campanula latifolia, the giant bellflower, is a perennial herb $50-125 \mathrm{~cm}$ in height, with large, toothed leaves [21]. Flowers are located on short peduncles in the axils of the leaves, directed upwards, in the paniculate inflorescence (Fig. 1, A). Calyx is glabrous with lanceolate lobes directed upwards. Corolla is wide bell-shaped, $40-60 \mathrm{~mm}$ in length, light purple or white [21]. The species is widespread almost all over Europe, in the Caucasus, Western Siberia, and Western Asia to the Himalayas [6]. C. latifolia belongs to the subsectio Eucodon (DC.) Fed. sectio Medium DC. of the genus Campanula [5]. According to the molecular data [18], C. latifolia belongs to the Campanula s. str. clade of the genus Campanula.

Fruits were collected at different stages of development in the northern outskirts of the city of Lviv, in Palanka village (Yavorivskyi district) in the cultivated conditions and fixed in $70 \%$ ethanol. The studied plants fully correspond to the species diagnosis. For

ISSN 1996-4536 (print) • ISSN 2311-0783 (on-line) • Біологічні Студії / Studia Biologica • 2019 • Том 13/№1 • C. 95-105 
the morphological study of the fruit, a binocular microscope MBS-10 (LZOS, Russia) was applied, and measurements were done using a measuring ocular. Anatomical structure of the fruit was studied on transverse and longitudinal sections on the temporary preparations. We performed the Meule reaction on lignified tissues with $1 \%$ solution of potassium permanganate, $10 \%$ hydrochloric acid and concentrated ammonia solution [2]. For anatomical studies, a light microscope XS-2610 (NINGBO, China) was applied. The AmScope MD (USA) digital ocular and the AmScope 3.7 software were used to take photographs. Morphological descriptions were done using a common terminology [1], and the structure of the pericarpium was studied according to I. Roth [19].

\section{RESULTS AND DISCUSSION}

Morphological structure and development of the fruit. Mature fruit of $C$. latifolia is an inferior pendulous trilocular dry capsule (Fig. $1 A, B$ ). In the center of the ovary, a central column is located with three septa attached to it (Fig. $1 C, 4 A-C$ ). The capsule contains a lot of seeds located in each locule on the convex placentas (Fig. 3 A). Placentas have ascendant and descendent globose lobes and are joined with carpel blade in its middle height with narrow band (Fig. 4, D). Seeds are 1.5-1.7 mm in length and 0.7-1.0 $\mathrm{mm}$ in width, oval, shiny, light brown. Above the placentas, the ventral sutures of carpels become visible dividing a central column into three portions (Fig. 4, F).

During fruit ripening the capsule changes the color from green to light brown and bends down. The mature fruit is $12-16 \mathrm{~mm}$ in length and $8-10 \mathrm{~mm}$ in diameter. The corolla dries gradually after anthesis, twists and persists for some time (Fig. 1, B). The stamens and style also fall out later.

At the initial stage of fruit opening, three dips of $4-5 \times 4-6 \mathrm{~mm}$ are formed in the lower part of the fruit. They are diamond-shaped (Fig. 1, D, E). A hippocrepiform slit appears on the lower edge of each dip. Subsequently, the dips become more pressed and their lower edge declines outward, providing a horse-shoe-like opening (Fig. 1, D). The dips are formed on the septa radii (Fig. 1, C) allowing seeds from each locule to disperse through two openings.

When the fruit dries, the parenchyma of the fruit wall between vascular bundles decays (Fig. 1, F). Valves that cover the openings bend outwards. On the inner side of the valves, wide edges are visible (Fig. 1, C).

Anatomical structure of the fruit. Histological zonal structure of the fruit wall was studied on the transversal sections of the fruit. The exocarpium is composed of one cell layer with non-lignified walls. Mesocarpium is multilayered (with 25-30 cell layers), mostly parenchymatous, with numerous vascular bundles. The endocarpium is uniceriate, non-lignified, composed of small flattened cells. The vascular system of the fruit is composed of one ring of amphicrybral vascular bundles (Fig. 2, D) arising from the vascular cylinder that enters the central column. In the lower part of the ovary, there are five vascuar bundles, while above the middle height of the ovary, there are 10-11 vascular bundles among which five large antesepalous bundles are located. In the large vascular bundles, xylem has a form of the ring surrounded by phloem (Fig. 2, A), that is peculiar and resembles the bundle structure in Psidium cuneifolium Ten. (Myrtaceae) [22]. In the ovary roof, a lot of vascular bundles supply nectary parenchyma (Fig. 2, F). The central vascular a cylinder above placentas is divided on three amphicrybral vascular bundles entering septa and supplying ovules.

ISSN 1996-4536 (print) • ISSN 2311-0783 (on-line) • Біологічні Студії / Studia Biologica • 2019 • Том 13/№1 • C. 95-105 

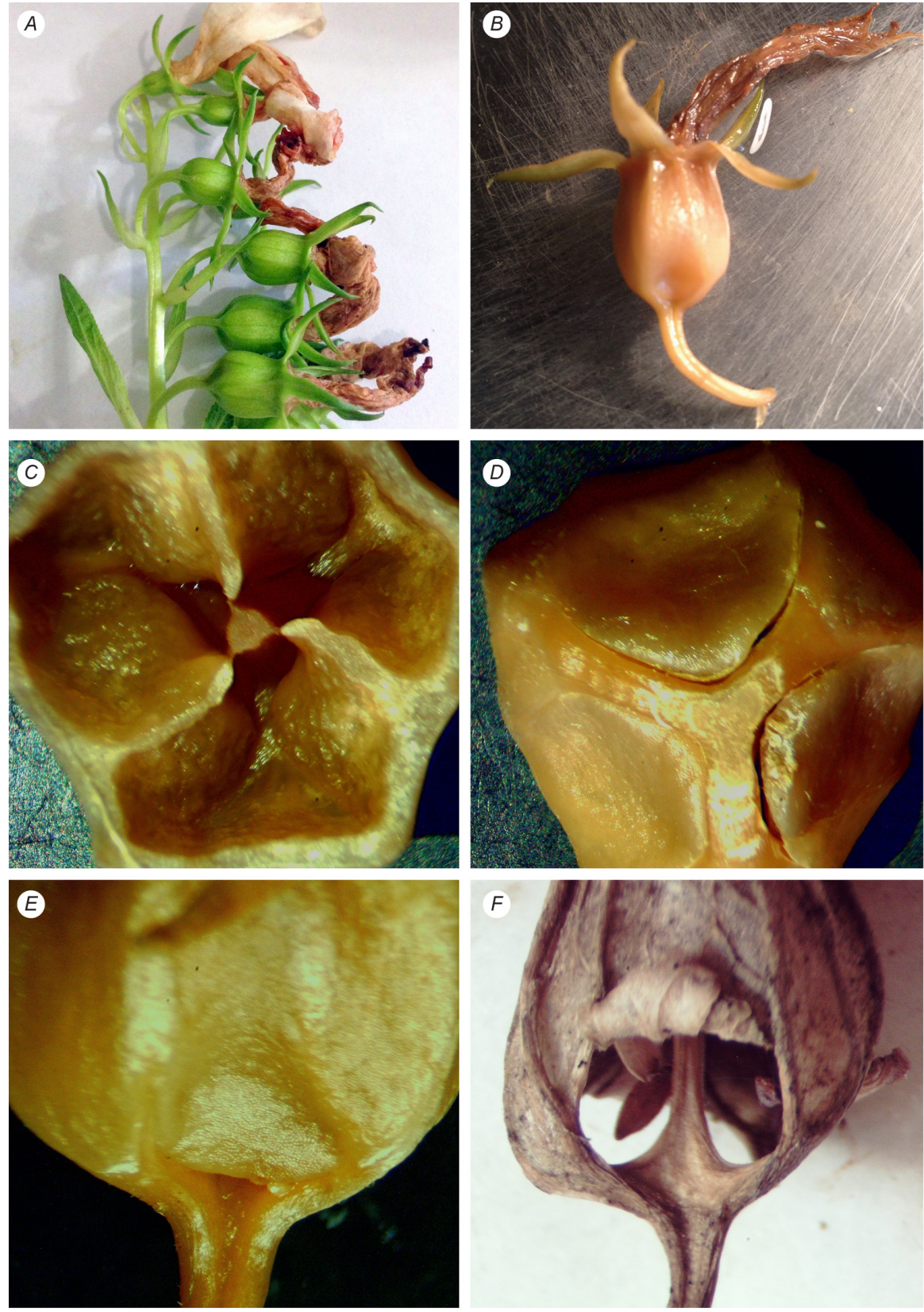

Fig. 1. Morphological structure of the fruit of $C$. latifolia: $A$ - fruiting inflorescence; $B$-young fruit; $C$-internal structure of the fruit, central column with attached septa are visible; $D$ - opened fruit from below, three horseschoe-shaped slits are visible; $E$ - beginning of fruit opening; $F$ - dried fruit with bent valves, central column is visible, septa is separated from a central column

Рис. 1. Морфологічна будова плоду C. latifolia: $A$ - суцвіття на стадії плодоношення; $B$ - молодий плід, $C$ - внутрішня будова плоду, центральна колонка, з'єднана з перегородками; $D$ - відкритий плід із підковоподібними щілинами; $E$ - початок розкривання плоду; $F$ - сухий плід із загорнутими клапанами та відокремленою від центральної колонки перегородкою

ISSN 1996-4536 (print) • ISSN 2311-0783 (on-line) • Біологічні Студії / Studia Biologica • 2019 • Том 13/№1 • С. 95-105 

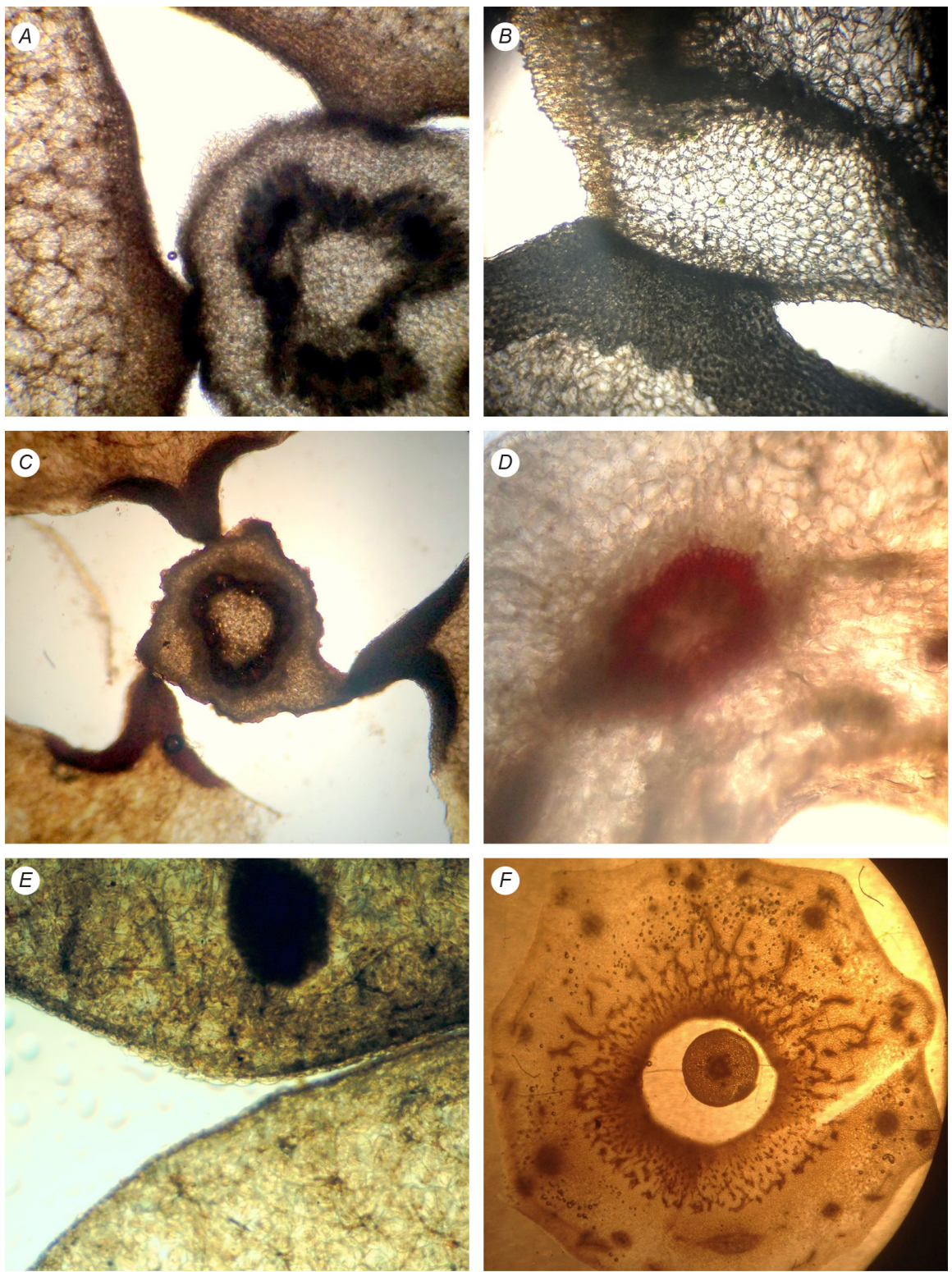

Fig. 2. Anatomical structure of the fruit of $C$. latifolia: $A$ - central column with attached septas at lower part of the fruit; $B$ - a short septa composed of lignified parenchyma; $C$ - central column with attached septa at the middle height of the fruit; $D$ - large vascular bundle with concentric structure; $E$-inner surface of fruit wall near septa (fragment of the section on Fig. 4, C); $F$ - the ovary roof and a style base, rich innervation of a nectary disc is visible

Pис. 2. Анатомічна будова плоду C. latifolia: $A$ - центральна колонка з приєднаними перегородками в нижній частині плоду; $B$ - коротка перегородка, сформована зі здерев'янілої паренхіми; $C$ центральна колонка з приєднаними перегородками на середній висоті плоду; $D$ - великий провідний пучок концентричної будови; $E$ - внутрішня поверхня стінки плоду поблизу перегородок (частина зрізу, представленого на рис. $4, C$ ); $F$ - дах зав'язі й основа стовпчика, помітні численні провідні пучки нектарного диску

ISSN 1996-4536 (print) • ISSN 2311-0783 (on-line) • Біологічні Студії / Studia Biologica • 2019 • Том 13/№1 • С. 95-105 


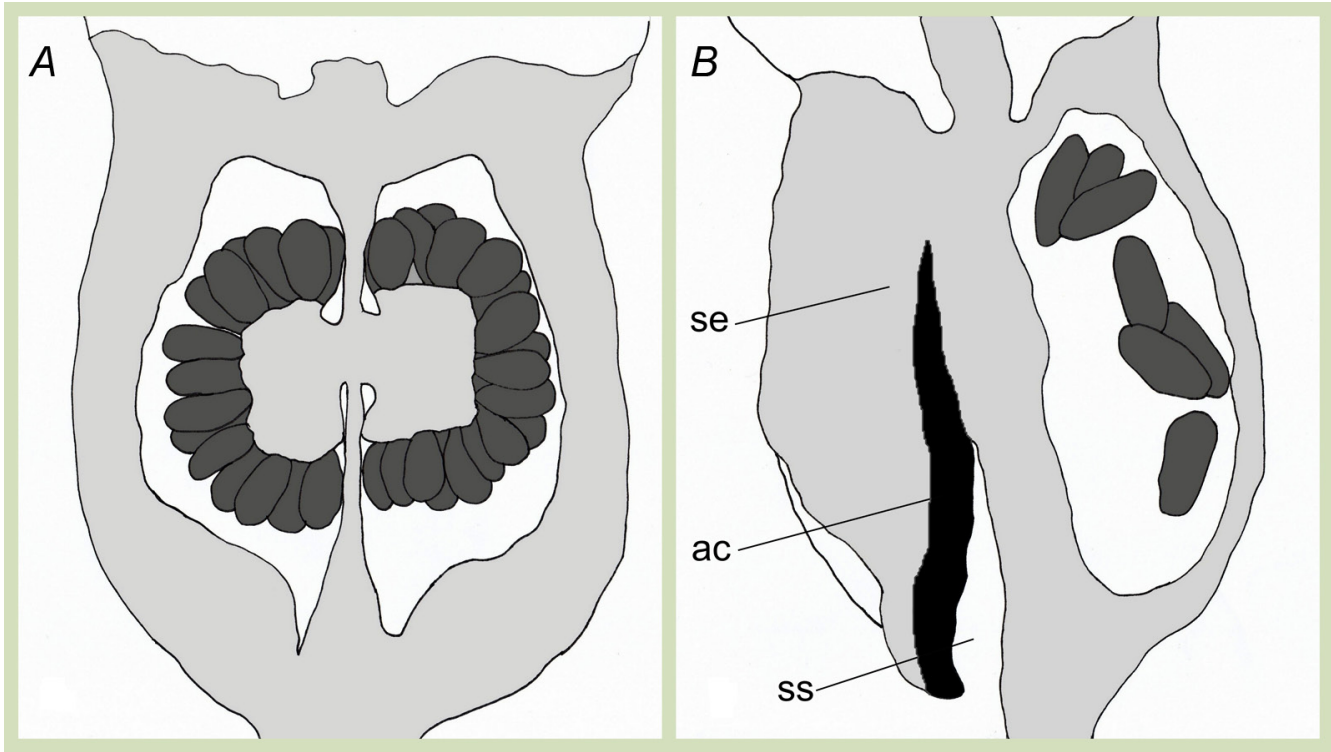

Fig. 3. Scheme of the longitudinal sections of the fruit of $C$. latifolia (ac - axicorn, se - septa, ss - septifragal slit): $A$ - tangential section; $B$ - radial section

Рис. 3. Схема поздовжнього зрізу плоду C. latifolia (ac - аксикорн, se - перегородка, ss - септифрагальна щілина): $A$ - тангенціальний зріз; $B$ - радіальний зріз

On the transversal sections of the upper part of the ovary, no lignified tissues except vascular tissue are visible. In the lower part of the ovary during fruit ripening, the inner cell layers of the mesocarpium and parenchyma of septa become lignified (Fig. 4, A-C). This lignified tissue contains isodiametric and polygonal cells with thick walls. At the ovary base the lignified mesocarp layer is thin and spread widely around each locule (Fig. 2, E). Above, the lignified parenchyma is located only in septa and neighboring parts of the fruit wall (Fig. 2, C). Near the middle height of the ovary, septa becomes radially elongated, while the lignified parenchyma is retained only on their proximal portion (Fig. 2, B). This lignified parenchyma is visible on the transversal sections at the level where placentas reach carpel blade, progressively decreasing above the placentas (Fig. 4, E). The rest tissues of the fruit wall except xylem and lignified parenchyma of the mesocarpium inner layer and septa are not lignified. The boundary between the lignified parenchyma of septa and parenchymatous central column is sharp, as boundary between lignified and non-lignified parenchyma are located distally (Fig. 4, B).

Before fruit wall opens, the septa detach from the central column just on the boundary between lignified and non-lignified parenchyma (Fig. 4, E). On the longitudinal sections, it is visible that lignified parenchyma has a form of a vertical band extending from a base of the ovary to placentas (Fig. 3, B). During fruit opening, this band of lignified parenchyma is fully detached from the central column, but fused in the column's upper part.

Morphological identity of axicorns and fruit dehiscence. A. Kolakovsky [11] considered that axicorns are important characteristics of the fruit in the Campanulaceae. He divided 42 recognized carpological fruit types of Campanulaceae on axicorn- and 

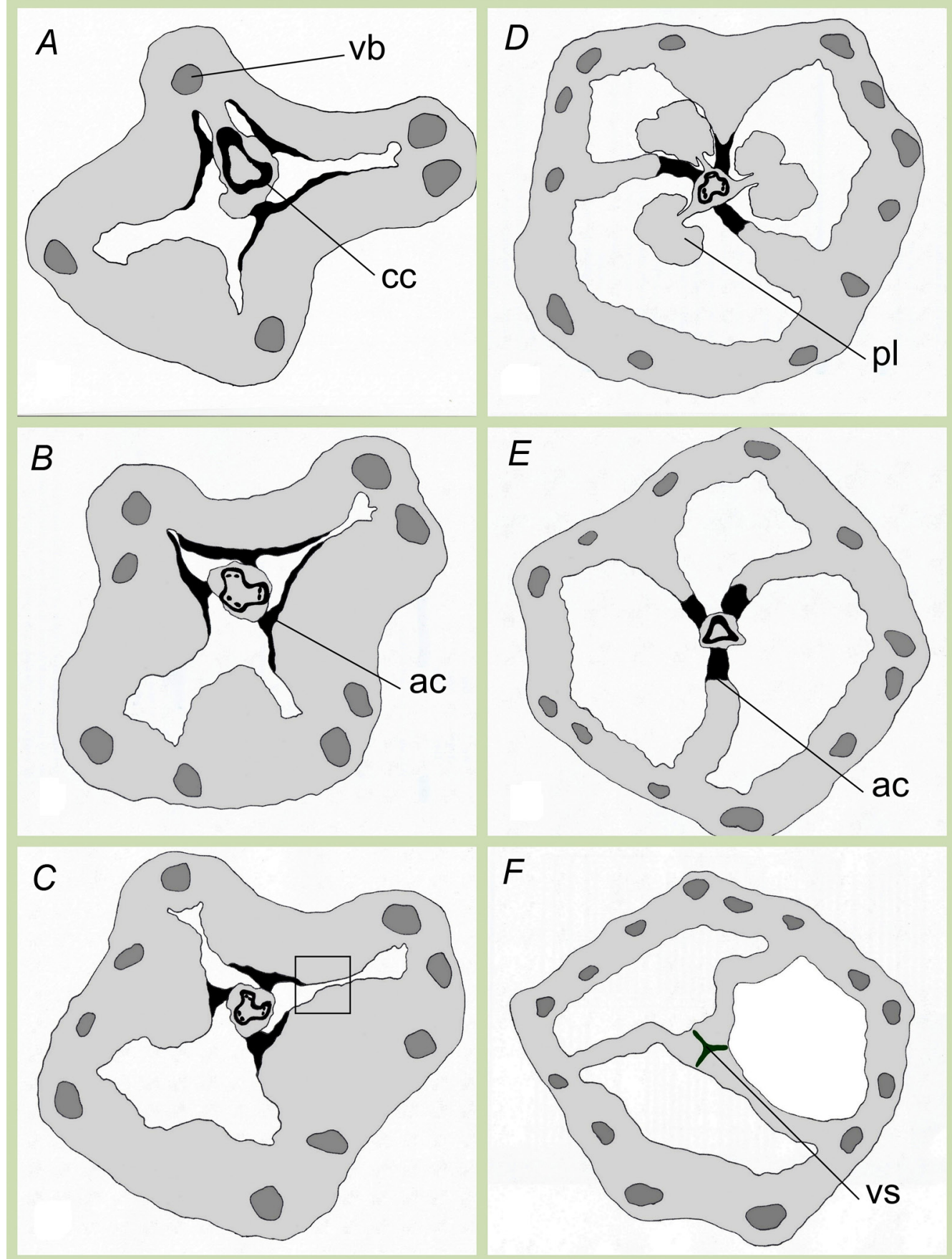

Fig. 4. An ascending series of transversal sections of the fruit of $C$. latifolia (ac-axicorn, $c c-$ central column, $\mathrm{pl}$ - placenta, vb - vascular bundle, vs - ventral suture)

Рис. 4. Висхідна серія поперечних зрізів плоду C. latifolia (ac - аксикорн, сc - центральна колонка, pl плацента, vd - провідний пучок, vs - вентральний шов) 
non-axicorn-types. According to A. Kolakovsky [11], an occurence of the axicorn in a process of fruit evolution in Campanulaceae has allowed more effective dissemination. A. Kolakovsky [11] classified a capsule of Campanula as of axicorn-type, axicornfissuricidal group with almost apical axicorns. On the schematic drawings of fruits of Campanula species (C. excisa Schleich. ex Murith, C. odontosepala Boiss., C. paradoxa Kolak., C. pyramidalis L.) provided by A. Kolakovsky (Table III, Fig. 3-6 in [11]) axicorns are located on a septa and touch a central column along the ovary or only in its part. Axicorn has a beak that makes a slit in the ovary wall. It was revealed that the tissue of axicorns is composed of transversely and longitudinally polygonal isodiametric cells with thick lignified walls containing numerous pit canals [11, 12].

I. Roth [19] based on citations of previous authors, wrote that a capsule of Campanula has wedge-shaped valves consisting of differently oriented fibers which shrink in different directions forming the pores in the interfasciculate sectors of capsule due to hygroscopic movements of the lignified portions of septa.

Other authors refer that axicorn of Campanula species bends as a horn and makes openings in the capsule wall [23]. In C. sibirica L., C. taurica Juz., C. talievii Juz. it resembles the half-moon producing an opening with one of its ends as it dries [16]. Axicorn is also defined as a tissue inside the fruit of some Campanulaceae which moves as it dries and perforates the fruit wall allowing a dispersal of seeds [20].

Our investigation provides an evidence that axicorn is not an organ sui generis inside the ovary of Campanula, but it is just a band of the lignified parenchyma of the mesocarpium and especially of septa which is differentiated early in fruit development (in the anthetic ovary). In C. latifolia, the axicorns are spread from the ovary base to ovary top as a narrow vertical band of tissue, well distinguished from the parenchymatous tissues on the transversal and longitudinal sections. As fruit dries, septa detach from the central column from base to top, while the lower margin of axicorns produces the hippocrepiform (horseshoe-shaped) opening in the ovary wall. The shape of axicorns in C. latifolia is complicated and mattock-like.

In previous works, a fruit of Campanula was defined as an inferior syncarpous capsule [9], containing axile placentation and laminal crescent slit of dehiscence [14].

A significant element of the fruit of $C$. latifolia is a central column. The mode of the dehiscence when septa detach from a central column is defined as septifragal, and fruit with such slits is to be classified as septifragal capsule. A crescent slit in the fruit wall is a criterion for hippocrepiformous dehiscence [8]. Consequently, the capsule in C. Iatifolia must be defined as inferior trilocular capsule with septifragal-hippocrepiform dehiscence.

I. Roth [19] supposed that the poricidal capsule of Campanula has derived from the loculicidal capsule. Later [3], fruits of Prismatocarpus L'Herit. and Wahlenbergia Shrad. ex Roth, primitive members of the Campanulaceae [13, 18], were classified as paracarpous and phragmocarpous (secondary syncarpous) capsule opened with a loculicidal apical valvae. More recent studies on fruit structure in the wahlenbergioid Campanulaceae - Prismatocarpus crispus L'Her. (Kericodon crispus (L'Her.) Cupido comb. nov.) and $P$. nitidus L'Her. [4] showed a presence of the lignified inner layer of mesocarpium and septa in both species. In these species, the fruits open longitudinally on 4-10 valves along the parenchymatous strands between the lignified bands in mesocarpium, accompanied by a separation of septa from a central column (Fig. 3 in [4]).

ISSN 1996-4536 (print) • ISSN 2311-0783 (on-line) • Біологічні Студії / Studia Biologica • 2019 • Том 13/№1 • C. 95-105 
The presence of the lignified parenchyma in septa and in the inner mesocarp zone was found also in C. latifolia fruit, but with two differences: lignification of septa is localized in their lower and proximal portions, and openings in the fruit wall develop as hippocrepiform slits at the fruit base, not longitudinally.

A peculiar structure and dehiscence of axicorn capsule was found in all species of Campanula [11] - the genus which is defined to be paraphyletic according the molecular data and comprises some other related genera [18]. As a lignified parenchyma of mesocarpium and septas was found in other clades of Campanulaceae, it may be the plesiomorphic condition for Campanula. The question stays, whether fruit dehiscence by means of axicorns is also plesiomorphic condition for Campanula, or it has arisen some times, in Campanula s. str. clade and in Rapunculus clade convergently.

Our hypothesis on morphogenesis of axicorn capsule is that early lignification (at anthesis) of septal and mesocarpic parenchyma prevents further growth processes in these parts of fruits. As a result, at time of fruit ripening, the boundary between parenchymatous and lignified fruit parts becomes a site of slit formation.

\section{CONCLUSIONS}

In C. latifolia, the lignified parenchyma in septa and in the inner mesocarp zone was found, and named an axicorn. The axicorns extend from the ovary base to ovary top as narrow vertical bands of the lignified tissue. As fruit dries, septa detach from a central column from base to top, while the lower margin of axicorns produces a hippocrepiform (horseshoe-like) opening in the ovary wall. The capsule of $C$. latifolia is defined as inferior trilocular capsule with a septifragal-hippocrepiform dehiscence at the fruit base. Most tissues of the fruit wall, except xylem and lignified parenchyma of the mesocarpium inner layer and septa are not lignified. Our assumption is that a unique fruit structure in Campanula species is developed on a basis of common histological differentiation of the fruit wall in Campanulaceae.

\section{ACKNOWLEDGEMENT}

We are very indebted to our anonymous reviewers for essential linguistic improvement of the manuscript.

1. Artjuschenko Z., TheodorovAl. Organographia illustrata plantarum Vascularium. Fructus, Leninopoli: Nauka, 1986, 392 p. (In Russian)

2. Barykina R.P., Veselova T.D., Deviatov A.G., Djalilova H.H., Iljina G.M., Chubatova N.V. Handbook of the botanical microtechniques, Moscow: Moscow Univ. Press, 2004, 287 p. (In Russian)

3. Bobrov A.V., Melikian A.P., Romanov M.S. Morphogenesis of fruits of Magnoliophyta, Moscow: Librokom, 2009, 400 p. (In Russian)

4. Cupido C.N., Weitz F.M. Kericodon (Campanulaceae s.s.), a new monotypic wahlenbergioid genus from South Africa. Kew Bull., 2016; 71: 56.

[DOI: https://doi.org/10.1007/S12225-016-9671-4]

5. Dremliuga N.G. The fruits' morphological peculiarities of species from section Medium DC. of genus Campanula L. in the flora of Ukraine. Chornomors'k. Bot. Zhurn., 2013; 9(1): 24-29. (In Ukrainian)

6. Fedorov A.A. Flora partis Europaeae URSS. Leningrad: Nauka, 1978, 213-239. (In Russian)

ISSN 1996-4536 (print) • ISSN 2311-0783 (on-line) • Біологічні Студії / Studia Biologica • 2019 • Том 13/№1 • С. 95-105 
7. Herrera F., Mitchell J.D., Pell S.K., Collinson M.E., Daly D.C., Manchester S.R. Fruit morphology and anatomy of the Spondioid Anacardiaceae. Bot. Rev., 2018; 84(4): 315-393. [DOI: https://doi.org/10.1007/s12229-018-9201-1]

8. Kaden N.N. More details about types of fruit dehiscence. Bot. J., 1964; 49(12): 1776-1779. (In Russian)

9. Kaden N.N. Types of fruits in plants of the middle strip of European part of USSR // Bot. J., 1965; 50 (6): 775-787. (In Russian)

10. Khafagi Azza A.F., El-Ghamery Abbas A., Ghaly Omran N., Ragab Osama G. Fruit and seed morphology of some species of Solanaceae. Taeckholmia, 2018; 38: 123-140. [DOI: https://doi.org/10.21608/taec.2018.13520]

11. Kolakovsky A.A. Family Campanulaceae. - Moscow, 1995. 92 p. (In Russian)

12. Lakoba P.V. Towards the anatomy of axicorn: an organ of Campanulaceae. Bulletin of the Academy of Sciences of the Georgian SSR, 1986; 123(1): 141-143. (In Russian)

13. Lammers T.G. Campanulaceae. The families and genera of vascular plants. Ed. VIII, Flowering plants - eudicots: Asterales / edited by K. Kubitzki; volume editors J.W. Kadereit and C. Jeffrey. Published. Berlin, Germany: Springer, 2007. Physical Description. 26-56.

14. Levina R.E. Morfologiya i ekologiya plodov / Morphology and ecology of fruit, Leningrad: Nauka, 1987. 160. (In Russian)

15. Miroshnichenko N.N. Some aspects of the reproductive biology of Campanula sibirica L., C. taurica Juz. and C. talievii Juz. in Crimea. Studia Biologica, 2014. 8(1): 161-170. (In Ukrainian) [DOI: https://doi.org/10.30970/sbi.0801.335]

16. Luna M.L., Giudice G.E., Grossi M.A., Gutierrez D.G. Development and morphology of the fruit and seed of the hemiparasite genus Jodina (Cervantesiaceae). An. Jard. Bot. Madrid, 2017; 74(1): e051.

[DOI: http://dx.doi.org/10.3989/ajbm.2444]

17. Mosyakin S.L., Fedoronchuk M.M. Vascular plants of Ukraine. A nomenclatural checklist, Kiev, 1999. 345 p.

[DOI: https://doi.org/10.13140/2.1.2985.0409]

18. Roquet C., Sáez L., Aldasoro J.J. et al., Natural delineation, molecular phylogeny and floral evolution in Campanula. Syst. Bot., 2008; 33: 203-217. [DOI: https://doi.org/10.1600/036364408783887465]

19. Roth I. Fruits of Angiosperms. In: Encyclopedia of plant anatomy. Eds W. Zimmermann, S. Carlquist, P. Ozenda, H.D. Wulff, Berlin: G. Borntraeger, 1977, Bd 10, Teil 1, pp. 200-675.

20. Stevens P.F. Angiosperm Phylogeny Website. Version 14, July 2017 [and more or less continuously updated since]. http://www.mobot.org/MOBOT/research/APweb/.[Accessed on 01.02.2019]

21. Visyulina O.D. Family of Campanulaceae Juss. Flora URSR. Vol. X. K.: izd-vo. AN URSR, 1961. pp. 401-435. (In Ukrainian)

22. Volgin S., Stepanova A. Morphology and vascular anatomy of the flower of sertain spesies of Psidium L. (Myrtaceae Juss.). Visnyk of L'viv Univ. Biology Ser., 2004; 37: 90-99. (In Ukrainian)

23. Zhinkina N.A. Campanulaceae. Anatomia seminum comparativa. Tomus 7, Dicotyledones Lamiidae, Asteridae, Petropoli: Nauka, 2010. 354-365. (In Russian)

ISSN 1996-4536 (print) • ISSN 2311-0783 (on-line) • Біологічні Студії / Studia Biologica • 2019 • Том 13/№1 • C. 95-105 


\section{МОРФОЛОГІЧНА Й АНАТОМІЧНА БУДОВА ПЛОДУ CAMPANULA LATIFOLIA L.}

\section{Р. Андрейчук, А. Одінцова}

Львівський національний університет імені Івана Франка вул. Грушевського, 4, Львів 79005, Україна e-mail: roksolana_roksa@i.ua

Внутрішня будова плоду у Campanula latifolia L. була вивчена під світловим мікроскопом. Метою нашого дослідження було уточнити спосіб розкривання плоду і з'ясувати, з якої частини зав'язі формується аксикорн, - своєрідний орган усередині зав'язі, і з яких тканин він складається. У плоді C. latifolia наявна центральна колонка, до якої прикріплюються три перегородки. Наше дослідження встановило, що в нижній частині плоду формуються три заглибини. Згодом по нижньому краю заглибини утворюється підковоподібна щілина, яка забезпечує фрормування отворів. Клапани, які вкривають отвори, загинаються назовні. Екзокарпій представлений одним шаром нездерев'янілих клітин. Мезокарпій багатошаровий, переважно паренхімний, з численними провідними пучками. Ендокарпій однорядний, нездерев'янілий, з дрібними сплощеними клітинами. Провідна система стінки плоду представлена одним колом з 10-12 крупних концентричних провідних пучків із кільцевою ксилемою. У нижній частині зав'язі внутрішня зона мезокарпію та паренхіма перегородок дерев'яніють. Ця здерев'яніла тканина містить ізодіаметричні багатогранні клітини з потовщеними оболонками. Перед розкриванням плоду помітно, що перегородки відокремлюються від центральної колонки зав'язі на межі між здерев'янілою і нездерев'янілою паренхімою. На поздовжніх зрізах здерев'яніла паренхіма має вигляд вертикальної смуги, що простягається від основи плоду до верхівки. Ця смужка тканини, яка диференціювалася на ранніх етапах розвитку плоду, добре відрізняється від паренхімних прилеглих тканин, і $є$ аксикорн. Форма аксикорна в C. latifolia $€$ складною, мотикоподібною. Нижній край аксикорна спричиняє формування підковоподібного отвору у стінці зав'язі. Наше дослідження показало, що аксикорн не є органом sui generis усередині зав'язі Campanula, а це лише тяж здерев'янілої паренхіми в мезокарпії і особливо в перегородках зав'язі, характерний також для інших представників родини Campanulaceae. Плід C. latifolia ми визначаємо як нижню тригніздну коробочку з септифрагально-підковоподібним розкриванням.

Ключові слова: дзвоники широколисті, нижня коробочка, стінка плоду, септифрагальне розкривання, підковоподібна щілина, аксикорн

Одержано: 09.04.2019

ISSN 1996-4536 (print) • ISSN 2311-0783 (on-line) • Біологічні Студії / Studia Biologica • 2019 • Том 13/№1 • С. 95-105 
